\title{
Developing Discipline Character and Preparing Integrated Thematic Approach for Early Childhood at TK Sabbihisma 1 Padang
}

\author{
Inawati $^{1, *}$, Rakimahwati ${ }^{1}$ \\ ${ }^{1}$ Department of Early Childhood Education, Faculty Of Education, Universitas Negeri Padang, Padang, Indonesia \\ *Corresponding author. Email: iwati1497@gmail.com
}

\begin{abstract}
The research is aimed at seeing how the implementation of learning the discipline of children aged early in centers of art and preparation for the approach of the thematic integrated in kindergarten Sabbihisma 1 Padang. The research is aimed at knowing the extent to the implementation of learning the discipline of children aged early in centers of art and preparation with an integrated thematic approach in TK Sabbihisma 1 Padang. The theory that is used in research this is, centers of art, centers of preparation, the system of learning, the implementation of learning, a component of learning, terms of learning, the stages of learning and the factors supporting and inhibiting the process of learning. The type of research is qualitative with a descriptive approach. The goal of the research is at TK Sabbihisma 1 Padang enrolled in the teaching of 201 $8 / 2019$. Source of data The main (primary), which is the source of the data that is retrieved researchers through interviews and observations with school principals and teacher classroom / primary teachers. Additional data sources (secondary), namely data sources beyond words and actions. Mechanical collection of data for interviews, observation, documentation, and questionnaires. Mechanical analysis of the data that is the reduction of data, presenting data, and the withdrawal of conclusion. The results of research related to the design of learning can be known that essentially in kindergarten Sabbihisma 1 Padang has a view that is positive towards the planning of learning. Implementation of the process of learning to teach in kindergarten Sabbihisma 1 Padang in the delivery of the material or materials of learning, teachers have to carry out well and in accordance with the procedures of curriculum in 2013 set by the government. Mater I delivered it intact with components among others are apperception, exploration or introduce material. Repeating the material to do a question and Java so that the child is active so as to build their own attitudes of behavior in life everyday with discipline. Evaluation of the is given in the form of test and non-test. The time of implementation of evaluation is carried out by teachers are routinely at the end of the competence base Glory $i$ for reviews. evaluation at the end of the semester and the middle of the semester.
\end{abstract}

Keywords: implementation, learning, TK Sabbihisma 1

\section{INTRODUCTION}

Children are an asset and the next generation of the nation. Kids are expected to grow and evolve as well - well, so it will be healthy adults who are physically, mentally, socially and personality. Suryana[1] states early childhood learning must be able to provide opportunities for children to get the learning process. This will have an impact on children's ability to think and insight as they continue their education to a higher level.

Discipline is the way society teaches children about moral behavior that is accepted by groups. According Kasmadi[2] discipline an act of orderly behavior and comply with various rules and regulations ". or discipline will affect the ways of behavior in social and emotional development of children, discipline will control the children and get them away from danger and will help people who live with them. The aim is to tell children which behaviors are good and which are bad and encourage them to behave to meet the required standards [3].

The center and circle method (preparation) is a method used to train children's development using a play approach [4]. The three types of games are playing sensorimotor (functional), playing roles, and playing development. When in the process of learning center and circle of children through four types of steps (scaffolding) to support children's development, namely: (1) footing of the playing environment; (2) footing before playing; (3) footing during play; (4) footing after playing.

Arifin \& Fardana[5] add approach centers has advantages: (1) children will learn better if the environment was created natural (naturalistic environment); (2) learning will be more 
meaningful (learning with meaning) if the child does what is learned not just knowing (learning by doing); (3) learning will be more meaningful and memorable.

Thematic learning has been done before, Sartika[6] with the research title "Integrated Thematic Learning Based on Scientific Approaches in Kindergarten ". Based on research conducted that the learning process experienced by children as a discovery learning effort. The process of developing the ability to think is a process of finding learning as meaningful learning.

The application of thematic learning must pay attention to the underlying flow, the basic principles of learning and the characteristics of thematic learning [7]. All of this is practiced in making plans, implementing in learning activities and conducting assessments in the process and end of learning activities. Thematic learning planning in kindergarten is arranged in the Daily Learning Program Design (RPPH) in kindergarten. In kindergarten emphasizes the interrelationship between aspects of development that are bound through themes or sub themes. Various things about the implementation of children's discipline learning in TK Sabbihisma 1 Padang. Based on the description of the background behind the above, the researchers wanted to see more in the "Implementation of Early Childhood Learning Discipline At the Center of Art and started with the Integrated Thematic Approach In kindergarten Sabbihisma 1 Padang "

\section{METHOD}

Early childhood according to the view of the three Research process in TK Sabbihisma 1 Padang using a qualitative approach and descriptive approach to the object of his research is the implementation of learning in TK Sabbihisma 1 Padang. The research was carried in TK Sabbihisma 1 Padang. Although the location of the school is less strategic, it is far from the highway. This school is very advanced in terms of academics / skills.

Researchers can come directly to this location easily because with the distance of more or less only about 500 meters, by driving a motorcycle from home to the location in about 5 minutes. The target of this research is the implementation of learning in TK Sabbihisma 1 Padang. In this learning implementation research the researcher focused his research on all aspects related to the implementation of learning in Padang Sabbihisma 1 Kindergarten.

The source of data in research is the subject of where the data can be obtained. According to Lofland \& Lofland, as quoted by Moleong[8] "the main data sources in qualitative research are words, actions, the rest are additions such as documents and others". Some data sources used in this study include (1) Primary data source (primary 2) Additional data sources (secondary), namely the source of the main data source that is the source of information in this study is the principal, who will provide direction to researchers in data collection, and provide information and recommendations to other informants such as school principals and teachers. So that all the data needed by researchers is collected according to the needs of researchers.

In the process of collecting data there are many methods used and adapted to the type of research. (1) Interview (Interview). The interview steps in this study: 1) determine who will be interviewed (respondent) 2) make contact with respondents regarding the interview, time and place of interview 3) prepare carefully in the sense of preparing the main questions, tools recorder that will be used and learn the main problems in the interview and alternative questions 4) start the interview and introduce yourself first, explain the purpose of the purpose briefly and carefully 5) conduct interviews according to the flow and strategy 6) recording interview data 7) checking the quality of the data 8 ) end the interview by leaving a good impression.

(2) Mulyana[9] observation method in his book Qualitative Research Methodology mentions participant observation by another name, namely participatory observation or involved observation. According to him, quoting from what Denzin said "participatory observation is a field strategy that simultaneously combines document analysis, interviews with respondents and informants, participation and direct observation and introspection." This method for researchers is very important for exploring social processes. The researcher uses this method to focus on the situation being analyzed, by demanding that he observe and participate at the same time. The researchers sensually carried out participant observation of the social situation in TK Sabbihisma 1 Padang such as school management, learning activities, uniqueness, as well as the existing infrastructure in TK Sabbihisma 1 Padang, naturally accompanied by recording and using supporting tools such as cameras. (3) Documentation. Researchers use the documentation method in research because: 1) is a stable, rich and encouraging data source 2) useful as evidence for a test 3 ) in accordance with qualitative research that is natural, in accordance with the context, born and are in context 4) relatively inexpensive and easy to obtain but documents must be searched and found 5) not reactive so hard to find with content study techniques 6) the results of content assessment will open up opportunities to expand the body of knowledge to something being investigated. (4) Questionnaire

The method of data collection is the means used by researchers in collecting research data [10]. According to Sukardi[11] there are four media to collect data in the research process. The use of the four media can be chosen one type, or a combination of several media, depending on the type of data expected by researchers. The fourth data collection is a questionnaire (questionnaire). Observations, interviews and documents.

After the data is collected, descriptive analysis techniques are used to analyze it, meaning that the researcher tries to redraw the data collected about the implementation of learning in TK Sabbihisma 1 Padang. According to [12] data analysis is the process of systematically searching and compiling data obtained from interviews, field notes and other materials, so that they are easily understood and the information can be shared with others. The process of data analysis is done after completing data collection. 
The technique used by researchers is Triangulation. Triangulation is a data validity checking technique that utilizes something other than the data for checking or comparison purposes [13]. In other words that with triangulation, researchers can recheck their findings by comparing the results of observations of the implementation of learning with the results of interviews with several informants or respondents.

In this study the authors use triangulation based on sources, meaning that it compares and checks the degree of trust in information obtained through different time and tools. This can be achieved by 1) comparing observational data with interview data, 2) comparing what people say in public with what they say privately, 3) comparing someone's perspective with various opinions and views, such as people with secondary education or tertiary institution, people who are and less, etc. 4) compare the results of interviews with the contents of a related document.

\section{DISCUSSION}

\subsection{Learning Planning in Sabbihisma 1 Padang kindergarten}

The findings obtained by research on the formulation of learning objectives made by the subject teacher in TK Sabbihisma 1 Padang is the competence of the indicator. Meanwhile, according to the teacher, if the learning objectives stated are more complicated, then it can be done by specifying more competencies that have been set, namely conveying competencies and indicators to children This is intended so that learning objectives can be achieved later after the child has finished learning or in other words the learning objectives are determined after the sub competencies are established and arranged based on the topic categories in the learning competencies. To achieve the desired learning objectives that it helps teachers in TK Sabbihisma 1 Padang develop learning objectives that will be taught in lesson planning. Designing good learning objectives means starting from the learning planning to the step of conveying the learning to the evaluation stage.

\subsubsection{Content/Material}

The material taught is mostly in the form of theory or very rarely in the form of practice due to time constraints. The learning process implemented in TK Sabbihisma 1 Padang look is good. The teacher has carried out the learning process by informing the material through stages of learning, from introducing the material to the child entering the area of the delivery of the material in full with components including apperception, exploration, or introducing the material and repeating the material.

\subsection{Learning Planning in Sabbihisma 1 Padang}

\subsubsection{Method}

Based on observations of teaching methods is very common lecture implemented, by teaching children in lectures and children listen Teachers sometimes stood talking teacher alternately ask for a child who can give information about the teacher walked and talked with the subject matter markers and write matters important things that are taught if the implementation of learning using the lecture method as well as stories and questions and answers after the activity sometimes ends with questions and answers and provides value for children who can answer. The reason they put forward personal obstacles in the innovation of a teacher's education is required to develop their abilities to support every side of the activities they do a teacher. If each teacher has the ability in the field of mature teacher learning will be right on target despite the limited time available.

The method of learning is largely determined by the teacher concerned. When the topic of teaching is discussed as broadly as in general teaching. A wide variety of methods will need to be used on their explanation that the election method in TK Sabbihisma 1 Padang less varied or more being watch is a lack caught them on the methods in accordance with the teaching competence-based else, and which shall be in compliance with the material taught. Then there is only one teaching experience among those who have taught for more than 10 years. These factors convince researchers that teaching experience and basic teaching knowledge are the main obstacles why they choose the lecture method dominantly as a choice and time constraints in providing direct practice in practice.

\subsubsection{Media}

Results of research by observation at the time of the master in TK Sabbihisma 1 Padang implementing learning that the medium used is an average teacher handbook only medium that can facilitate the child to more quickly understand a subject never functioned as they should so monotonous learning. In the learning document in the form of RPPH it is found about the use of media such as direct drawing (painting), LCD and multimedia, but rarely or even not seen the most used media is books..

The conclusion that the selection of the right media for a material cannot be applied by the teacher is very strong this assumption that they do not have the ability to use the right time with the right media. On the other side of the teaching culture that they have been up to now is how curriculum targets can be achieved regardless of whether the child really understands or not. The conclusion that the TK Sabbihisma 1 Padang attempts to use the media to be delivered in learning activities. From this data conclusions can be drawn if the media used are very limited. 


\subsubsection{Implementation of learning in general}

Based on the results of the test questionnaires can be concluded that there is some perception of children in Sabbihisma 1 Kindergarten Padang. Based on the results were obtained in the first questionnaire (preparatory) for "persistence learn" the child answered "always" amounted to 1 point about the interim who answered "often" there is one point about. Next, to answer "sometimes: there are 4 questions. For" tenacious in learning "the child answered" often "amounts to 2 grains of matter while the answer" sometimes "there is one point about, and who answered" never "there is one point about.

Furthermore, for the "interest to learn" the child answered "always" amounts to 2 grains of matter, who answered "often" there are two grain matter, for "independence in learning" the child answered "always" amounts to 1 item matter while the answer "Now and sometimes" there are six items about. For a "quick tired of" the child answered "often" amounts to 2 grains of matter while the answer "sometimes" there is one point about, who answered "never" there is one point about. To "maintain the opinion of" the child answered "always" amounts to one point about the interim who is answered "often" there are two grain matter, who answered "sometimes" there are grains of matter. For "faith toward a thing" the child answered "often" amounts to 1 grain matter, who answered "sometimes" there are two grain matter, and to "like find and resolve the problem" children answered "always" amounts to 1 item matter while the answered "often" there are two grain matter, who answered "sometimes" there are grains of matter, and who answered "never" there is one point about.

\subsection{Learning Evaluation at Sabbihisma 1 Kindergarten Padang}

The evaluation in TK Sabbihisma 1 Padang refers to the assessment format is very monotonous. Assessment of cognitive aspects is carried out based on post-test. According to the child, the assessment is carried out by giving direct questions the results of who can answer correctly and most correctly then he will get higher grades compared to children whose grades are less true. In addition the evaluation of learning is carried out using a test and non-test format such as giving a statement or by psychomotor observation. From various information especially from the three informants, information can be obtained that in giving an evaluation there is not too difficult. They reuse the material previously carried out evaluation. As a result the child does not find it difficult to answer and the results can be said to be good and satisfying. If it is examined based on existing theories it is known that evaluation or assessment is the final component in the learning process evaluation system is not a way of functioning to see the success of children in the learning process. However, it also functions as feedback for teachers on their performance in learning processing. Through evaluation we can see deficiencies in the use of various learning system components.

\section{CONCLUSION AND SUGGESTIONS}

Based on the results of the study conducted by researchers at Sabbihisma 1 Padang Kindergarten can be concluded. Related lesson plan can be seen that basically in Sabbihisma 1 Kindergarten Padang has a positive view of learning planning. Teachers at TK Sabbihisma 1 Padang in formulating objectives if the learning objectives are expressed more complicated, they are specific Competency predetermined. Or in other words the learning objectives are determined after the existence of sub competencies are determined and arranged based on top categories in learning competencies.

Implementation of the learning process at Sabbihisma 1 Kindergarten Padang in delivery of materials or learning, teachers have implemented properly and in accordance with the procedures of curriculum in 2013. It can be seen that teachers deliver teaching materials with different stages of learning, overlapping with the approach of the scientific. Material delivered in full with components including apperception, exploration or introduction of material. Repeating the material by asking Java so that children are active so they can build their own behavioral attitudes in everyday life.

Selection of old methods of teaching them the syllabus, RPPH, lectures, performance of work, questions and answers, discussion, and storytelling. Most of them practice directly in accordance with the demands of the 2013 curriculum that are based on the scientific.

Media used teacher in TK Sabbihisma 1 Padang average usually direct media. In addition, the average teacher only uses a handbook. Media that should be able to make it easier for children to understand more quickly about a material is not always functioned as it should so that learning seems monotonous like record type $r$.

The researcher suggests several points regarding the learning process as follows: 1) In terms of setting learning objectives, researchers recommend that teachers adjust to the content standards, the applicable curriculum is the 2013 curriculum. 2) Then in terms of media selection and learning methods. Ideally the media is an inseparable part of the learning process for the achievement of educational goals in general. While those who deliver or use the media are teachers, the teacher acts as a manager of learning resources. 3) For the assessment or evaluation, both formative and summative, advised on teacher in TK Sabbihisma 1 Padang in order to make an evaluation tool which is not just to measure and improve the quality of children in terms cognitive, but also further optimized the development of the child in terms of psychomotor and affective children, as well as children in learning that hope child. 
[6] D. Sartika, "Implementasi Pembelajaran Tematik Terpadu Kontekstual di RA Mutiara Miftahul Jannah Sabah Balau Lampung Selatan," Universitas Islam Negeri Raden Intan, 2019.

[1] D. Suryana, "Pembelajaran Tematik Terpadu Berbasis Pendekatan Saintifik di Taman Kanak-kanak," J. Pendidik. Anak Usia Dini, vol. 11, no. 1, pp. 67-82, 2017.

[2] Kasmadi, Pendidikan Islam dalam Membangun Karakter Anak Usia Dini (Konsep dan Praktek dalam Islam). Jakarta: PT Raja Grafindo Persada, 2013.

[3] S. Lukitasari, "Deskripsi Kedisiplinan Anak Usia 5-6 Tahun di KB/TK Pedagogia.," J. Pendidik. Anak Usia Dini, vol. 3, no. 6, pp. 231-240, 2017.

[4] I. Arifin, Kepemimpinan PAUD Menerapkan Pusat Studi Kasus Persiapan Nasional Paud /Kb Anak Saleh Malang. Yogyakarta: Aditya Media, 2009.

[5] A. K. Arifin and N. A. Fardana, "Peran Pendidik PAUD dalam Mengimplementasikan Pendidikan Karakter Melalui Metode Pembelajaran Sentra dan Lingkaran," J. Psikol. Pendidik. dan Perkemb., vol. 3, no. 3, 2014.
[7] M. Muklis, "Pembelajaran Tematik," J. Fenom., vol. IV, no. 1, pp. 63-76, 2012.

[8] L. J. Moleong, Metodologi Penelitian Kualitatif, Ketigapulu. Bandung: PT Remaja Rosdakarya, 2013.

[9] D. Mulyana, Metodologi Penelitian Kualitatif. Bandung: PT Remaja Rosdakarya, 2008.

[10] Sugiyono, Memahami Penelitian Kualitatif. Bandung: Alfabeta, 2012.

[11] Sukardi, Metodologi Penelitian Pendidikan Kompetensi dan Praktiknya. Jakarta: Bumi Aksara, 2013.

[12] Sugiyono, Metode Penelitian Kuantitatif, Kualitatif dan $R \& D$, 15th ed. Bandung: Alfabeta, 2012.

[13] B. S. Bachri, "Meyakinkan Validitas Data Melalui Triangulasi pada Penelitian Kualitas," J. Teknol. Pendidik., vol. 10, no. 1, 2010. 